\title{
Perception of Eco-Friendly Farming Practices of Paddy Crop among the Tribal Farmers of Baihar Block of Balaghat District (M.P.), India
}

\author{
Neha Markam*, Abha Tiwari and V.K. Pyasi \\ Department of Extension Education, JNKVV, Jabalpur, India \\ *Corresponding author
}

\section{A B S T R A C T}

\begin{tabular}{|l|}
\hline Key w ord $\mathbf{s}$ \\
Eco-friendly \\
practices, Extent of \\
perception, Tribal \\
farmers
\end{tabular}

Tribal's generally adopt their traditional techniques of farming which they get from their heritage and this farming community which is due to their low economic and awareness status usually adopts low cost farming practices. They treat land as a mother so, they emotionally as well as culturally attached with nature. hence, it becomes necessary to have an better recognition about their extent of perception regarding eco-friendly farming practices so present study on extent of perception of tribal paddy grower farmers towards eco-friendly farming practices of paddy crop was done during year 2015-16 at Baihar block of Balaghat district, Madhya Pradesh. Farmers were selected from 10 villages of Baihar block. Total 120 respondents were selected through proportionate random sampling method. It was found that higher percentage of respondents having medium level of education, and medium level of farming experience majority of farmers belong to middle age groups with medium level of annual income and low level of information source utilization. It was concluded from the study that maximum respondents $(47.50 \%)$ had medium extent of perception followed by low (35.83\%) and high (16.67\%) extent of perception towards eco-friendly paddy farming practices.

\section{Introduction}

Eco-friendly farming is a comprehensive approach describing the way of farming which supports both agricultural production and biodiversity conservation working in harmony together to improve the livelihood of rural communities. According to Mishra (2013) three important goals of eco agriculture are: Enhance rural livelihoods, Conserve or enhance biodiversity and eco-system services, Develop more sustainable and productive agricultural system without polluting the soil, water and surrounding area. Eco-friendly farming combines some agricultural approaches like Integrated Pest Management, Integrated Nutrient Management, Integrated Weed Management, Soil, Water and Residue Management practices. These approaches advocated for use of resistant crop varieties, balanced nutrient supply, use of cow dung, cow urine, use of vermin-compost, use of parasites and predators, use of traps, neem oil and extract, crop rotation, mulching, use of biodegradable pesticides etc.

Paddy is world's second most important crop and it contributes an important part in national 
economy of India. Around 65 per cent of total Indian population eats rice (Nipuna Rice Products 2009). Paddy fields are common sight throughout India, paddy is cultivated at least twice a year in most parts of the country. So the practices which are adopted for paddy crop production make a greater impact in our nature and lives.

Paddy is one of the major crop of Madhya Pradesh with area, production, and productivity of 1882.6 thousand ha, 2775 thousand tones and $1474 \mathrm{~kg} / \mathrm{ha}$ respectively (International Plant Nutrition Institute 201314). The socio cultural as well as the economical life of tribal farming community of selected region is integrally associated with paddy cultivation hence, present study was conducted in Baihar block with following objectives:

To study the personal profile of tribal paddy grower farmers

To access their extent of perception regarding eco-friendly paddy farming practices.

\section{Materials and Methods}

The present study was conducted in Baihar block of Balaghat district (Madhya Pradesh) purposively because this block contains highest tribal's population than other blocks of Balaghat district. The block comprises of 330 villages out of which 10 villages namely Amgaon, Bhari, Birwa, Kohka, Mohbatta, Pipariya, Katangi, Singbagh, Newargaon and Mowala were selected. Through the use of proportionate random sampling (proportion of 22.8 of total population) a fixed proportion of respondents were selected from each village to make the total sample size of 120 respondents. The data were collected through wellstructured and pre tested interview schedule. The data were analyzed through mean and percentage. For the study of extent of perception regarding these practices 8 major management practices of eco-friendly farming were selected which are using in paddy cultivation namely; Soil conservation, water conservation, Seed management, Integrated weed management, Integrated disease and pest management, Integrated nutrient management, Storage management and Residual management practices.

The total score obtained by each respondent from all the eight practices was the perception score of an individual respondent was calculated by using the index as described below:

\section{Total obtained score \\ Total obtainable score $\times 100$}

After thorough review of relevant literature and in consultation with experts of relevant field the potential a index was prepared for measuring their perception regarding ecofriendly farming practices. The extent of perception was classified in three groups viz. low, medium and high on the basis of percentage.

\section{Result and Discussion}

\section{Personal profile of tribal paddy grower farmers}

It is evident from the table 1 that majority of the farmers $(52.50 \%)$ belonged to middle age group and only 25 per cent farmers belonged to young age group. In case of education higher percentage $(29.17 \%)$ was educated up to primary school level while 26.66 per cent were high secondary school level educated. Farming experience is also one of the critical factor for building the dimension of their perception, in this study 45.83 per cent of respondents belong to medium level while 35.83 per cent were from high level of farming experience. 
Table.1 Personal profile of paddy growers

\begin{tabular}{|c|c|c|c|}
\hline Variable & Category & No. & Percentage $(\%)$ \\
\hline \multirow[t]{3}{*}{ Age } & Young (19 to 35 years) & 30 & 25.00 \\
\hline & Medium (36 to 50 years) & 63 & 52.50 \\
\hline & Old age (51 and above) & 27 & 22.50 \\
\hline \multirow[t]{4}{*}{ Education } & Illiterate & 23 & 19.17 \\
\hline & Up to primary & 35 & 29.17 \\
\hline & Up to high school & 30 & 25.00 \\
\hline & High secondary \& above & 32 & 26.66 \\
\hline \multirow{3}{*}{$\begin{array}{c}\text { Farming } \\
\text { experience }\end{array}$} & Low (Up to 15 years) & 22 & 18.34 \\
\hline & Medium (16 to 25 years) & 55 & 45.83 \\
\hline & High $(>25$ years $)$ & 43 & 35.83 \\
\hline \multirow{3}{*}{$\begin{array}{l}\text { Annual } \\
\text { income }\end{array}$} & Low (up to $50,000 \mathrm{Rs}$. ) & 40 & 33.34 \\
\hline & $\begin{array}{c}\text { Medium (51,000 to } 1,00,000 \\
\text { Rs. })\end{array}$ & 55 & 45.83 \\
\hline & High (> 1,00,000 Rs.) & 25 & 20.83 \\
\hline \multirow[t]{3}{*}{$\begin{array}{l}\text { Sources of } \\
\text { information } \\
\end{array}$} & Low & 58 & 48.33 \\
\hline & Medium & 38 & 31.67 \\
\hline & High & 24 & 20.00 \\
\hline
\end{tabular}

Table.2 Extent of perception regarding major eco-friendly farming practices of paddy

\begin{tabular}{|c|c|c|c|}
\hline $\begin{array}{c}\text { S. } \\
\text { No. }\end{array}$ & Practices & Mean & Rank \\
\hline 1. & Soil conservation & 2.13 & III \\
\hline 2. & Water conservation & 1.99 & V \\
\hline 3. & Seed management & 2.50 & II \\
\hline 4. & \multicolumn{3}{|l|}{ Integrated weed management } \\
\hline a. & Mechanical weed management & 1.80 & VIII \\
\hline b. & Cultural weed management & 1.99 & $\mathrm{~V}$ \\
\hline c. & Biological weed management & 1.45 & $X$ \\
\hline 5. & \multicolumn{3}{|l|}{ Integrated disease and pest management } \\
\hline a. & Cultural control & 2.09 & IV \\
\hline b. & Mechanical control & 1.70 & IX \\
\hline c. & Biological control & 1.80 & VIII \\
\hline 6. & Integrated nutrient management & 1.89 & VI \\
\hline 7. & Storage management & 2.86 & I \\
\hline \multirow[t]{2}{*}{8.} & Residual management & 1.84 & VII \\
\hline & Overall mean & \multicolumn{2}{|c|}{2.00} \\
\hline
\end{tabular}


Table.3 Distribution of respondents according to their extent of perception towards eco-friendly practices in rice cultivation $(n=120)$

\begin{tabular}{|c|l|c|c|}
\hline S. No. & \multicolumn{1}{|c|}{ Categories } & No. of respondents & Percentage \\
\hline $\mathbf{1}$ & Low (45 to 75$)$ & 43 & 35.83 \\
\hline $\mathbf{2}$ & Medium (76 to 105) & 57 & 47.50 \\
\hline $\mathbf{3}$ & High (106 to 135) & 20 & 16.67 \\
\hline & Total & 120 & 100 \\
\hline
\end{tabular}

Annual income is that factor which decides their perception regarding adoption of any practice, in case of annual income majority $(45.83 \%)$ of farmers having medium level of annual income. The level of sources of information was low, a large percentage $(48.33 \%)$ of farmers comes under low level of information sources.

\section{Extent of perception towards eco-friendly farming practices}

The findings related to extent of perception of farmers towards eco-friendly paddy farming practices indicate that the perception score for storage management practices was highest which was followed by seed management and soil conservation practices, while perception for biological weed management practices having lowest score (Table 2). It was concluded that majority of the respondents which is 47.50 per cent had medium extent of perception while, 35.83 and 16.67 per cent of the farmers had low and high extent of perception respectively towards these practices of paddy farming (Table 3). The findings indicates that by and large, farmers in the study area had low to medium level of perception on eco-friendly farming practices of rice cultivation. It is reported that the concept of in eco-friendly agriculture despite gaining its popularity among the farmers, its systematic and scientific application were not properly trained under different farming situations. This calls for hand-on training programmes for farmers by the experts in this field to improve their knowledge and skills towards eco-friendly farming technologies. This finding finds support with the work of Chapke (2000), Bhople and Borkar (2002), Kushwah (2003), Shakya et al., (2009), Singh and Devi (2013), Dhenge et al., (2014) and Patidar et al., (2015).

The profile of respondents reveals that majority of paddy growers belonged to middle age, low educated, medium level of experience in farming, medium level of annual income and with low level of utilization regarding information experience. It clearly presents the picture of their awareness status regarding new agricultural technology. They having high extent of perception regarding storage management practices because their storage techniques are more nearer to new techniques of eco-friendly storage, but they have poor perception regarding biological management of weeds, they doesn't know about biological herbicides and bio control agents. This condition arise a need for training and demonstrations regarding latest eco-friendly practices and technologies for stimulating their adoption as well as diffusion among the tribal population of this area. At last the overall perception score shows that highest percentage of farmers having medium level of perception regarding above listed categories of ecofriendly technologies of paddy crop which directly influences their adoption regarding these practices. The study reveals the status of eco-friendly farming in a tribal area which is consider as zone close with nature, so it will be dangerous for our environment and for our 
lives. Government should take a necessary step and come forward with number of programs and demonstrations and different strategies to make them aware regarding ecofriendly agriculture.

\section{References}

Anonymous report. 2014-16. Department of Farmer Welfare and Agriculture development, Baihar block of Balaghat district (M.P.).

Bhople RS and Borkar RD. 2002. Biofertilizers farmers' attitude and adoption. Agriculture Extension Review March-April, 18-20.

Census of India 2011. District Census Handbook 24 (XII-B). www.censusindia.gov.in

Chapke R. 2000. Knowledge and adoption of farmers about bio-control measures. Maharastra Journal of Extension Education XIX: 41-47

Dhenge SA, Mankar DM and Wakle PK. 2014. Knowledge level of farmers about integrated pest management practices of paddy. An International Quarterly Journal on Environmental Sciences 6: 27-33.

Kushwah R. 2003. Behavior of vegetable growers towards plant protection measures in solanacious crop in Ghatigaon block of Gwalior district. M.Sc. (Ag.) thesis (Unpublished) JNKVV, Jabalpur, M.P.

Mishra M. 2013. Role of Eco friendly Agricultural Practices in Indian Agriculture Development. International Journal of Agriculture \& Food Science Technology 4(2): 11-15.

Nipura Rice Products. 2009. Major Rice Producing Nations.www.nipura.com

Patidar S and Patidar H. 2015. A study of perception of farmers towards organic farming. International Journal of Application in Engineering and Management 4(3): 269-277.

Shakya SK, Bhadoriya SK, Garg SK, Daipuria OP and Sharma N. 2009. Impact of training programs as perceived by trained farmers with regards to organic farming practices. Paper presented in National Seminar. RVSKVV, Gwalior. 113p.

Singha AK and Devi Sony. 2013. Analysis of Factors Influencing Farmers' Knowledge on Resource Conservation Technologies (RCTs) in Rice (Oryza sativa L.). Cultivation. Journal of Agriculture Science 4(1): 13-19.

\section{How to cite this article:}

Neha Markam, Abha Tiwari and Pyasi, V.K. 2018. Perception of Eco-Friendly Farming Practices of Paddy Crop among the Tribal Farmers of Baihar Block of Balaghat District (M.P.), India. Int.J.Curr.Microbiol.App.Sci. 7(05): 1945-1949.

doi: https://doi.org/10.20546/ijcmas.2018.705.228 